IDEAs IN EcLlagy AND EVILUtion 12: 26-27, 2019

doi:10.24908/iee.2019.12.4.c

(C) 2019 The Author

Received 13 May 2019; Accepted 22 July 2019

Commentary

\title{
Cliffs, trees, and ground-nesting raptors
}

\author{
Miguel Ferrer \\ Miguel Ferrer (타errer@ebd.csic.es) , Applied Ecology Group, Estacion Biologica de Doñana, CSIC. Avd Americo \\ Vespucio s/n 41092 Sevilla, Spain
}

In their recent paper, Martínez-Abraín and Jiménez (2019) presented an appealing hypothesis about the potential evolutionary consequences of being able to build nests on trees for diurnal raptor species. According to the authors, the fact that only some species of cliffnesting raptors provide sticks, making a "real nest" on the cliff is due to evolutionary load of formerly tree nesters. They provide an analysis showing that probably those species that do not provide nest material when nesting in cliff are the only truly rupicolous species.

This suggestion is a very interesting and original one, and allows the authors to make phylogenetically testable predictions. Additionally, some discussion about the previous origin of these species would be inferred from current nesting habits. For example, large eagles like Golden eagle (Aquila chrysaetos), Spanish imperial eagle (A. adalberti), European Imperial Eagles (A. heliaca), Bonelli's Eagle (A. fasciata) and others that supply nest on cliffs - or even they don't breed on cliffs at all-may have evolved in forests. I would like to add some additional considerations to this hypothesis.

Nesting on trees or cliffs is not the only possibility for diurnal raptors. Even though it is true that most of them breed on trees or cliffs, several species of diurnal raptors also nest on the ground. Some are frequently or totally ground-nesters, like the Tawny eagle (Aquila rapax), Pale harrier (Circus macrourus), Montagu's harrier ( $C$. pygargus), or Hen harrier (C. cyaneus) (Volchanetskii and Yal'tsev 1934, Volchanetskii 1937). In other species, ground-nesting occurs less frequently, as in the cases of the Pallas' fish eagle (Haliaeetus leucoryphus), the Bald eagle (H. leucocephalus), the Ferruginous Hawk (Buteo regalis), the Black-chested Buzzard-Eagle (Geranoaetus melanoleucus), the Osprey (Pandion haliaetus), the Golden eagle, the Egyptian Vultures (Neophron percnopterus) and the Peregrine (Falco peregrinus), among others (Lokemoen and Duebbert 1976, Newton 1979, Novaro et al. 2000 , Monson 2001, Katzner et al. 2003, Gangoso and Palacios 2005, Martin 2005, Oparin 2008, Ellis et al. 2009, Pagel et al. 2010, Ratcliffe 2010). Ground nests are generally found in remote areas without large presence of both humans and terrestrial predators. Typically they are more frequent-but not exclusivelyon islands (Del Hoyo et al. 1994, Ellis et al. 2009, Ferguson-Lees and Christie 2001). Nevertheless, ground nesting among raptors continues to be a confounding nesting behavior, especially in areas where there are potential terrestrial predators and elevated substrates available.

Whatever the reason for this behavior, there is a clear difference among true cliff nesters and true tree nesters (sensu Martínez-Abraín and Jiménez 2019) because the supply or lack thereof for sticks follows the same pattern observed by these authors when breeding occurs on cliffs, i.e. true tree-breeders nesting on the ground still use sticks and build a real nest on the ground, which is not the case with true cliff-breeders. This point, in my opinion, reinforces the hypothesis of Martínez-Abraín and Jiménez, showing that some evolutionary load is working on true tree-nesters and that they have to supply sticks even on cliffs and/or the ground when they breed.

Several suggestions can be made about how this flexible behavior of selecting where to breed has evolved, and why some raptor species seem much more flexible than others. But from a conservation point of view, being able to breed on trees or alternatively cliffs must have been a critical factor in responding to human interference during the $20^{\text {th }}$ century. 


\section{References}

Delhoyo, J., Elliott, A., andJ. Sargatal. 1994. Handbook of the Birds of the World, Vol. 2. New world vultures to guineafowl. Lynx Edicions, Barcelona, Spain.

Ellis, D.H., Craig, T., Craig, E., Postupalsky, S., Larue, C.T., Nelson, R.W., et al. 2009. Unusual raptor nests around the world. Journal of Raptor Research 43:175198. CrossRef

Ferguson-Lees, J., and D.A. Christie. 2001. Raptors of the World. Christopher Helm, London, U.K.

Gangoso, L., and C.J. Palacios. 2005. Ground nesting by Egyptian Vultures (Neophron percnopterus) in the Canary Islands. Journal of Raptor Research 39:186187.

Ignazi, G.O. 2015. Ground nesting by black-chested Buzzard-Eagles (Geranoaetus melanoleucus). Journal of Raptor Research 49(1): 101-104. CrossRef

Katzner, T.E., Bragin, E.A., Knick, S.T., and A.T. Smith. 2003. Coexistence in a multispecies assemblage of eagles in central Asia. The Condor 105(3): 538-551. CrossRef

Lokemoen, J.T., and H.F. Duebbert. 1976. Ferruginous hawk nesting ecology and raptor populations in northern South Dakota. The Condor 78(4): 464-470. CrossRef

Martin, C. 2005. Ground nesting by Bald Eagles. Ontario Birds 23:31-33.
Martínez-Abraín, A., and J. Jiménez. 2019. Stick supply to nests by cliff-nesting raptors as an evolutionary load of past tree-nesting. Ideas in Ecology and Evolution 12: 21-25. CrossRef

Monson, C.S. 2001. Ground-nesting Ospreys in Utah. Journal of Raptor Research 35:257-258.

Newton, I. 2010. Population ecology of raptors. A\&C Black.

Oparin, M. L. 2008. Recent fauna of ground-nesting birds in Transvolga steppes and its dynamics in the 20th century. Biology Bulletin 35(4): 422-427. CrossRef

Pagel, J.E., Patton, R.T., and B. Latta. 2010. Ground nesting of Peregrine Falcons (Falco peregrinus) near San Diego, California. Journal of Raptor Research 44(4): 323-326. CrossRef

Ratcliffe, D. 2010. The peregrine falcon. A\&C Black.

Volchanetskii, V.K. 1937. About the ornithofauna of the Volga-Ural steppes. Transactions of the Khar'kov Scientific Research Institute 21-81.

Volchanetskii, I.B., and N.P. Yal'tsev. 1934. On the Ornithofauna of the Eruslan Steppe, the Autonomous Republic of Volga Germans. Uch. Zap. Saratov. Gos. Univ 11(1): 63-93. 